\title{
Claude Lefort e a crítica de "A propósito da questão judaica" de Marx: dialética e ideologia
}

\author{
Claude Lefort and the Critique of "On the Jewish \\ Question" of Marx: Dialectics and Idology
}

\author{
Ruy Fausto \\ Universidade de São Paulo | São Paulo | Brasil \\ Professor Emérito da Faculdade de Filosofia, Letras e Ciências Humanas
}

\section{RESUMO}

Como o seu título indica, o texto tem como objeto as consideraçóes críticas de Lefort - ver o ensaio "Droits de l'homme et politique", incluído em L'Invention Démocratique, les limites de la domination totalitaire - contra a crítica dos direitos do homem, desenvolvida por Marx no seu artigo de juventude "A propósito da questão judaica", publicado em I843, nos Anais Franco-Alemães (revista que Marx fundara com o publicista Arnold Ruge). Depois de expor as razóes de Marx e de Lefort, o presente escrito envereda por vários caminhos. Há primeiro uma tentativa de expor as duas séries de argumentos em forma, que se pretende, rigorosamente dialética. Segue-se uma apresentação mais histórico-estrutural, que introduz consideraçôes sobre os chamados "dois liberalismos" (revolucionário e utilitarista). Explora-se, em seguida, a filosofia subjacente ao artigo de Marx nos Anais..., o que leva de novo um desenvolvimento teórico-dialético, e depois, histórico, sobre a questão do humanismo e do antihumanismo. Depois de analisar algumas objeções, de marxistas e de liberais, endereçadas à crítica lefortiana, o autor tenta uma avaliação crítica das posições de Lefort, o que conduz ao problema geral das relaçôes democracia/ capitalismo, em Lefort, e para além dele.

\section{PALAVRAS-CHAVE}

Claude Lefort; Direito; Liberalismo; Marxismo; Humanismo.

\begin{abstract}
As the title indicates, this text aims at the critical considerations of Lefort - see the essay "Droits de l'homme et politique", included in L'Invention Démocratique, les limites de la domination totalitaire against the critique of the rights of man published in I843, in the Franco-German Annals (journal founded by Marx with the publicist Arnold Ruge). After exposing the keys arguments of Marx and Lefort, the present writing goes through several ways. There is first an attempt to expose both series of arguments in a form strictly dialectical. There follows a more historical-structural version, which introduces considerations on the so-called "two liberalisms" (revolutionary and utilitarian). Then, we explore the philosophy underlying Marx's article in the Annals... which takes a new theoreticaldialectical development, and then, historical, about the question of humanism and anti-humanism. After analysing some objections from both Marxists and liberals, addressed to Lefortian criticism, the author undertakes a critical evaluation on Lefort positions, which leads to the general problem of democracy and capitalism relationship, not only in Lefort but and beyond.
\end{abstract}

\section{KEY WORDS}

Claude Lefort; Law; Liberalism; Marxism; Humanism. 
A crítica de Claude Lefort a "A propósito da questão judaica" de Marx, contida num artigo publicado na revista Libre, em 1980, e, depois, inserido em L'Invention Démocratique. Les limites de la domination totalitaire (I98I) ${ }^{\mathrm{I}}$, se tornou, justificadamente, um texto clássico. $\mathrm{O}$ artigo representa certamente uma das melhores críticas que já se fizeram a Marx e ao marxismo. Como o seu título o indica, ele toca num tema que voltou à tona, desde há uns quarenta anos, depois de um relativo letárgio e que não cessa de indagar o presente: os direitos do homem.

Tratar da crítica que faz Lefort à crítica de Marx aos direitos do homem - porque é disto que se trata - é um trabalho cheio de riscos, seja pela amplitude do leque de problemas (históricos, teóricos e políticos) que ele abre, seja pelas dificuldades que oferece a sua discussão. $\mathrm{O}$ artigo de Marx visa dois escritos de Bruno Bauer sobre "a questão judaica": um pequeno livro A questão Judaica (Bauer, I843b), e um artigo "A aptidão de judeus e cristãos de hoje a se tornarem livres", publicado pelas Vinte e uma folhas da Suiça (Bauer, I843a).

Bruno Bauer, filósofo neo-hegeliano e neo-fichteano ao qual Marx estivera bastante ligado, sustenta a tese de que os judeus não podem reclamar a emancipação (isto é, o gozo pleno dos direitos civis e políticos), porque a sua religião é estranha ao progresso. Como eles não teriam participado verdadeiramente do processo histórico, não teriam direito a reclamar esses direitos. ( $\mathrm{O}$ cristão também não os merece enquanto cristão, mas teria ido mais longe, o cristianismo é o "judaísmo efetivado", a religião que está como que às portas das luzes). A certa altura do seu arrazoado, Bauer se pergunta, de forma mais específica, se os judeus poderiam almejar razoavelmente o gozo dos "direitos do homem". A sua resposta é negativa.

Marx dá uma resposta inversa à de Bauer. Mas a resposta de Marx (isto é, sua defesa da tese da legitimidade da emancipação dos judeus) é curiosamente ambígua. Segundo Marx (ou segundo o Marx que assina esse artigo) se os judeus fazem jus à emancipação e se merecem, portanto, se elevar até o gozo dos "direitos do homem", é paradoxalmente porque o judaísmo encarna o dinheiro e a usura e, de forma mais geral, o egoísmo. E isso porque a sociedade atual — que, em oposição à medieval, se caracterizaria por uma separação entre sociedade civil e Estado - seria uma sociedade onde reina o egoísmo, e na qual os homens aparecem como átomos ou mônadas desligadas umas das outras. Nela, caberia ao Estado o polo oposto-complementar da comunidade, mas tratar-se-ia de uma comunidade ilusória. Os direitos do homem - carta da emancipação apenas

I O artigo se chama "Droits de l'homme et politique". Foi publicado, pela primeira vez, na revista Libre, n. 7, Paris, Payot, 1980 e, depois, em L'Invention Démocratique, les limites de la domination totalitaire, Paris, Fayard, I98I (utilizo a reedição de 1994) 
"política" e não da emancipação "humana" - exprimiriam, assim, em essência, "os direitos desse homem egoísta".

$\mathrm{Na}$ mesma linha de considerações, Marx afirma que, ao se liberar de toda dependência para com uma religião específica, o Estado moderno, longe de exprimir uma negação da religião em geral, paradoxalmente a confirma. Por isso, é legítimo que o homem religioso tenha acesso aos direitos que exprime esse Estado sem religião "particular", mas, por isso mesmo, religioso em essência. Em suma, os judeus têm direito à emancipação (política) porque ao conceder esses direitos aos judeus concede-se, na realidade, direitos "de egoísta" a um grupo humano que precisamente encarna o egoísmo; assim como é legítimo o acesso desse grupo religioso a um Estado que, contra as aparências, é essencialmente, religioso.

O nosso tema será a crítica que faz Claude Lefort a essas teses, mas muito em especial a da visão marxiana da emergência da sociedade moderna e do significado dos "direitos do homem". A questão levantada por Lefort, se exprime, em forma resumida, do seguinte modo: seria mesmo verdade que os direitos do homem exprimem direitos do "homem egoísta", do homem-átomo ou mônada, o qual corresponderia ao homem da sociedade moderna? Ou eles representam (e poderíamos acrescentar: ou representam também) outra coisa?

\section{I}

Marx analisa a Declaração dos Direitos do Homem de I789-I79I, a Declaração de 1793 , a Constituição de 1793 , e a constituição termidoriana de I795. Faz também referência à Constituição da Pensilvânia. Referindo-se às Declarações, Marx escreve: "Distingue-se os direitos do homem enquanto tais, dos direitos dos cidadãos" (Marx, I97I, pp. IO2-IO3). Na realidade, as declarações não fazem uma referência explícita a essa distinção. É ainda Marx quem escreve: "Que é o homem distinguido do cidadão? Nenhum outro senão o membro da sociedade burguesa" (Ibid.). De onde ele conclui: "Antes de mais nada, constatemos que os chamados direitos do homem, os direitos do homem em oposição aos direitos dos cidadãos, nada mais são do que os direitos do membro da sociedade burguesa, isto é, do homem egoísta, do homem separado do homem e da coletividade [Gemeinwesen]" (Ibid.). ${ }^{3}$ Lefort resume esses textos (cf. Lefort, [1980] 1994, p. 52) do

2 A posição de Marx é, assim, mais avançada do que a de Bauer, no sentido de que ele legitima a emancipação dos judeus, e Bauer não. Mas o seu argumento incorpora um estereótipo do judeu, que enquanto caracterização da "essência" do judaísmo é evidentemente falso - um estereótipo que foi amplamente explorado pelos antissemitas.

3 Passo rápido sobre a questão da emancipação dos judeus e sobre a discussão de Marx com Bauer a esse respeito, já que isso só nos interessa aqui, na medida em que se relaciona com a questão da natureza da sociedade moderna e dos direitos do homem. $\mathrm{O}$ elemento central da argumentação de Marx, é a diferença entre a "emancipação política" 
seguinte modo:

Dessas proposições, Marx extrai uma série de consequências relativas ao estatuto da opinião, principalmente da opinião religiosa, da liberdade, da igualdade, da propriedade e da segurança. [Da opinião, ele diz] que ela é reconhecida como legítima no momento em que ela parece [ser] um equivalente espiritual da propriedade. Da liberdade [...] que, definida, como 'o poder que pertence ao homem de fazer tudo o que não prejudica o direito do outro' [Marx escreve, literalmente, "de nenhum outro" (Marx, I97I, pp. IO4-IO5), RF], supōe que 'cada indivíduo é uma mônada, isolada, voltada [replié sur] para si mesma' (Lefort, [1980] 1994, p. 52). Da propriedade [...], que definida juridicamente como o direito que pertence a todo cidadão de gozar e de dispor a seu arbítrio de seus bens, de suas rendas, do fruto do seu trabalho e da sua indústria, ela faz com que cada homem encontre no outro homem 'não a realização da sua liberdade, mas pelo contrário o limite da sua liberdade' (Marx, 197I, pp. 106-I07). Da igualdade, que ela oferece apenas uma nova versão da teoria da mônada. Da segurança, enfim [...] que ela 'é o conceito social supremo da sociedade burguesa, o conceito da polícia, segundo o qual toda sociedade só está lá para garantir a cada um de seus membros a conservação da sua pessoa, dos seus direitos e da sua propriedade' (Ibid., pp. IO8-IO9). E, em resumo, que ela 'é a garantia do seu egoísmo' (Lefort, [1980] 1994, pp. 52-53).

Lefort contesta essa leitura através de uma bateria de argumentos bastante articulados. $\mathrm{Na}$ base deles, está uma recusa em aceitar o esquema da separação sociedade civil/ Estado, proposto por Marx, como paradigma explicativo do advento da modernidade. Mas essa recusa só é desenvolvida no final da argumentação. Antes dela, Lefort insiste na ideia de que a declaração não atomiza; os direitos proclamados não implicam em atomização, mas antes em comunicação e circulação de ideias entre os homens (cf. Lefort, [1980] I994, p. 58). A representação monadológica seria antes fruto de uma ilusão ideológica de que Marx, ele próprio, teria sido vítima. É verdade que os termos em que foram redigidos os artigos ressaltam esse aspecto, mas haveria algo de ilusório em supor que nisso

e a "emancipação humana" (pós-burguesa), dois elementos que Marx acusa Bauer de confundir. De fato, há ambiguidade a esse respeito nos textos de Bauer. Marx dirá que Bauer "levanta questôes que seu problema [Aufgabe] não comporta, e resolve problemas que não resolvem a sua questão" (Marx, I97I, pp. 58-59). Observe-se que Marx elogia o livro de Bauer (A Questão Judaica, ver supra), o qual daria prova de "audácia, penetração, espírito [e] profundidade" (Ibid., pp. 50-5I). Na realidade, o artigo ("A aptidão dos judeus e dos cristãos...", ver supra) parece superior ao livro, pela energia do discurso e do argumento. Em geral, sobre o texto de Marx, permito-me referir a Fausto (I983). 
está o essencial da declaração (cf. Ibid., p. 56). O efeito maior da declaração iria, na realidade, em direção contrária.

Ao mesmo tempo contraprova e consequência essencial dos argumentos críticos: a leitura de Marx não suportaria a experiência do nosso tempo, que é a do totalitarismo. Esta "lança uma luz sinistra sobre as fraquezas" da interpretação de Marx. O totalitarismo se edifica sobre as ruínas dos direitos do homem. Entretanto, sob esse regime, o homem se acha dissociado do homem e separado da coletividade, como ele nunca o foi no passado" (Ibid., p. 53). E não porque o homem teria sido reduzido à vida privada e ao estatuto de mônada, isto é, "porque ele goza[ria] do direito de ter opinióes, liberdade, propriedades, e segurança, mas porque esse gozo lhe é proibido" (Ibid.). Finalmente, essa dissociação não vem da separação entre sociedade civil e Estado, mas do fato de que este último detém "o princípio de todas as formas de socialização e de todos os modos de atividade" (Ibid.).

Assim, a interpretação de Marx como que obliteraria a compreensão do totalitarismo e desarmaria a sua crítica: "[...] a problemática de Marx é posta em xeque pelos acontecimentos do nosso tempo" (Ibid., p. 55). Esse desarmamento diante do totalitarismo teria as suas raízes na visão que tem Marx da passagem à modernidade política, e no sentido que ele empresta à Declaração de direitos. Na genealogia que propõe, Marx teria perdido de vista o fato de que o Estado monárquico já efetuara o trabalho de "compressão", de reunião numa universalidade ideal que Marx atribui ao Estado que emerge com a época moderna (aliás essa constituição da universalidade teria se processado a partir de poderes locais, mais do que da dispersão de indivíduos atomizados). A mutação cujo teor se discute significaria antes uma "desincorporação" em relação à pessoa de um monarca, e uma separação das ordens do poder, do saber, e da lei. Marx teria esquecido as mudanças, que ocorreram aí, em termos de liberdade. "[Ele] ignora estranhamente a supressão das múltiplas proibições que pesavam sobre a ação humana antes da revolução democrática, sob o Ancien Régime, [...] ignora o alcance prático da Declaração de direitos [...]" (Ibid., p. 57). De um modo geral, ele não levanta a questão fundamental de saber "quais são em tal ou qual sociedade — tal ou qual formação social — os limites impostos à ação de seus membros, as restrições que se introduzem ao seu estabelecimento, à sua circulação, à sua frequentação de certos lugares, à sua entrada em certas carreiras, à mudança de suas condiçôes, ao seu modo de expressão e de comunicação [...]" (Ibid., pp. 56-57).

Essas considerações serão justificadas por uma análise detalhada da crítica marxiana. Assim, a propósito da crítica por Marx à ideia de liberdade que contém a Declaração de 89-9I ("liberdade é o poder que pertence ao homem de fazer tudo o que não prejudica o outro", - a declaração de 93, também citada por Marx é um 
pouco diferente), Lefort observa que ele destaca o lado negativo "não prejudicar", ao qual ele subordina o lado positivo "poder fazer tudo o que...", que abre um espaço de relacionamento entre os indivíduos e não de isolamento monadológico (cf. Ibid.). Mais grave do que isto, Marx ignora simplesmente certos artigos ("essa omissão deve ser assinalada por que ela dá prova do seu preconceito"), (Ibid., p. 57). Trata-se precisamente dos artigos (Io e II) da Declaração de 89-9I, em que se expressa a liberdade de opinião ("ninguém pode ser inquietado pelas suas opinióes mesmo religiosas..." e "a livre comunicação dos pensamentos e das opiniōes é um dos direitos mais preciosos do homem, todo cidadão pode falar, escrever, imprimir livremente, salvo...”), (Ibid., p. 58). Para Lefort, Marx interpretaria esses artigos de maneira a ligá-los à propriedade (que, como se sabe, é afirmada como direito, e até sacralizada enquanto direito, no último artigo da declaração de 89-9I). Mas na realidade, pondera Lefort, os dois artigos, e principalmente o segundo, excedem "a metáfora da propriedade", trata-se de afirmar o direito precioso entre todos "de sair de si-mesmo e de se ligar aos outros pela palavra" (Ibid.). Lefort tenta assim desmontar a construção de Marx, a sua concepção da gênese da modernidade que, entre outras coisas, induziria opacidade na leitura do fenômeno moderno do totalitarismo. Na base desse engano está a operação hermenêutica que lê "homem egoísta", "homem mônada" ou átomo social, lá onde a Declaração fala em homem, hermenêutica que leva a uma espécie de projeção da "propriedade" ou do "direito de propriedade" sobre o significado do conjunto da Declaração.

\section{II}

O exame mais profundo, que se impõe aqui, da crítica de Lefort deve ser, ao mesmo tempo, lógico e histórico. Porém ele exige uma exploração prévia da crítica que Marx faz às Declarações e à sociedade que elas exprimem. O procedimento de Marx tem muito o sentido de uma crítica a uma ideologia. Ocasião para rediscutir a questão geral da natureza da ideologia.

Se muito se escreveu sobre ideologia, praticamente não se tratou da questão no quadro de uma lógica dialética. Se a dialética é a apresentação ou teoria das significações "em movimento", o discurso ideológico entra no âmbito do seu objeto, e é mesmo um objeto privilegiado dela, por uma razão um pouco paradoxal. A ideologia se insere no campo de análise da lógica dialética menos por ser um discurso em movimento do que pela razão contrária e negativa, a de ser um discurso que bloqueia o movimento (é que esse bloqueio implica, evidentemente, que a ideologia aponta para o movimento no plano do "em si", isto é, no plano essencial). Quando Marx afirma que o "homem" das Declaraçôes é o "homem 
egoísta", isto significa que, naquele contexto, a significação "homem" se reverte 4 em "homem egoísta". A crítica, expressa em termos dialéticos, põe o fato de que o termo "homem", no plano do "em si", ou da essência, não conserva a sua identidade. Ele não é igual a si mesmo, mas vem a ser o equivalente de "homem egoísta". É precisamente esta operação que é bloqueada pelo discurso ideológico. Se, no plano essencial, "homem" se reverte em "homem egoísta", no plano imediato, o da aparência ou do "para si", ele se apresenta como igual a si mesmo: homem $=$ homem. Assim, o bloqueio se revela a operação (ou a contra-operação) fundamental da ideologia, expressa nos termos de uma lógica dialética. E essa é a significação lógico-dialética da crítica de Marx.

E o que pretende, por sua vez, Lefort? Lefort recusa a legitimidade da crítica de Marx. Tentemos exprimir dialeticamente também essa recusa. Na realidade, a crítica de Lefort implica dizer que "homem" não remete a "homem egoísta", mas, efetivamente, a "homem"; que "homem" é igual a "homem", ao contrário do que Marx pensa. Assim, Lefort sustenta que a crítica operada pelo texto de Marx - essa crítica que considera como ideológica a identidade "homem = homem" - representa ela mesma um discurso ideológico.' Haveria aí, da parte de Marx, uma queda na ideologia, que viria, sem paradoxo, do fato de ele denunciar um movimento ideológico lá onde, essencialmente, não existe ideologia. Uma falsa desmistificação que, por ser falsa, é em si mesma mistificante.

Até aqui tentei dar formulações de tipo dialético à crítica que Marx endereça às Declaraçôes, e ao questionamento dela por Lefort. Seria possível, entretanto, iluminar uma coisa e outra de um modo menos lógico-dialético e mais histórico.

Voltemos, para isso, ao argumento de Marx. Num plano mais histórico (a rigor, lógico-histórico), dizer que o "homem" que neles aparece se resolveria, na realidade, no "homem egoísta" significa, a meu ver, interpretar o discurso das Declaraçôes enxergando uma convergência entre ele e o que viria a ser o discurso dos economistas. Para Marx, aquele "homem" a que as Declaraçôes se referem teria, em essência, muito do homo economicus dos economistas.

O que nos leva a consideraçôes de ordem mais geral. Costuma-se distinguir dois tipos de liberalismo (ou de discurso liberal): o liberalismo chamado frequentemente de "revolucionário", mas também de "axiomático" e "dedutivo", e o

4 Melhor do que "interverte", que, em geral, emprego nesse contexto, porque este último verbo vale mais precisamente quando se trata da passagem a um termo propriamente contraditório.

5 Lefort acredita, aliás, que essa carga ideológica estaria não só em Marx, mas no próprio texto das Declaraçôes. Entenda-se, teríamos aí algo como uma ideologia "às avessas": as Declaraçôes se apresentariam, no plano imediato, como um discurso individualista, mas elas introduziriam, de fato, essencialmente, não o fechamento de cada homem em si mesmo, mas, o seu contrário, a "comunicação" entre os homens. 
liberalismo dito "utilitarista", mas também "indutivo" . A meu ver, o que Marx pretende fazer é reconhecer, sob o palimpsesto das Declaraçôes, em que se fala do "homem" (e que mergulha fundo na narrativa revolucionária) a prosa utilitarista do liberalismo "indutivo" que gira em torno do homo economicus.

Por sua parte, Lefort relegitima a verdade do liberalismo revolucionário das Declaraçôes. O discurso liberal-revolucionário não remeteria a outra coisa, senão a ele mesmo. Ele teria uma verdade intrínseca. Seria um erro, e um erro perigoso, supor que uma redução como aquela a que procede Marx, se justifica.

Assim, se no registro mais estritamente lógico-dialético, a resposta de Lefort significava que, nesse contexto pelo menos, "homem" = "homem" - a significação "homem" remete de direito a ela mesma —, nesse segundo registro, que é mais propriamente lógico-histórico, a análise conduz a dizer que o discurso revolucionário ("axiomático" ou "dedutivo") é em si mesmo legítimo, e indene a qualquer conversão hermenêutica que descobriria a sua verdade no que diz o liberalismo utilitarista.

\section{III}

Aquém dessas "operaçōes" críticas — e antes de discutir a legitimidade da crítica de Lefort, questão que terá um lugar importante nesse texto - gostaria de explorar mais de perto o contexto filosófico da crítica que Marx endereça aos direitos do homem, em "A propósito da questão Judaica".

Que representa, do ponto de vista filosófico, a posição de Marx, naquele momento da sua história intelectual e política?

Perguntar-se pela filosofia que Marx professa naquele momento é, acima de tudo, enfrentar a questão do "humanismo", porque o "homem" aparece visivelmente no centro das suas consideraçôes. Como se situa o Marx dos Anais..., relativamente ao humanismo? A filosofia dos Anais... é humanista? A discussão dessas questões exigirá um excurso pela questão mais geral do humanismo.

6 A distinção entre os dois liberalismos (sob essa forma, pelo menos) é usualmente atribuída a Michel Foucault (cf. Foucault, 2004, p. 40 e ss), a quem se deve as qualificações "axiomático" e "dedutivo", acrescentadas ao liberalismo revolucionário, e "indutivo", acrescentada ao liberalismo utilitarista. Mas há um outro livro, bem anterior e muito importante - mencionado numa das séries bibliográficas indicadas por Foucault, mas que, salvo erro, este não utiliza expressamente, La Formation du Radicalisme Philosophique (I90I) de Élie Halevy - em que o tema está presente. De fato, os dois liberalismos são um dos motivos centrais do livro de Halevy, obra mais ou menos esquecida na França, e que, entretanto, graças a uma tradução já antiga, se tornou um clássico no mundo anglo-saxão. Nem mesmo a reedição dela nos anos 1990 (La Formation du Radicalisme Philosophique, três volumes, Paris, PUF, I995) com comentários e posfácios assinados por especialistas, parece ter despertado grande interesse. Para o nosso tema, ver, por exemplo o vol. I, pp. I48-I49 e pp. I73-I75. 
O Marx dos artigos dos Anais... é, sem dúvida, humanista. Essa resposta pode parecer surpreendente, já que, no artigo que examinamos, ele faz a crítica dos direitos do homem. No entanto, essa crítica se efetua num registro que é de fato humanista, no sentido de que o fundamento dela é o homem como "ser genérico"? $\mathrm{Na}$ realidade, o conceito fundante da crítica no artigo que examinamos é o conceito de origem feurbachiana - Marx é bastante feurbachiano, até a primeira ruptura, a de I845 - de "ser genérico" [Gattungswesen]. O "ser genérico" representa o homem efetivamente real, no qual o indivíduo não se opõe mais ao gênero como acontece na sociedade até aqui, e em particular na sociedade burguesa, mas se reconcilia com ele. Marx opõe, o "homem egoísta" ao homem como "ser genérico". Toda a sua crítica se constrói com base nessa distinção, que é, filosoficamente homóloga à distinção política, entre a emancipação simplesmente política (a dos direitos do homem, e em geral, a da Revolução Francesa), e a "emancipação humana", que iria além dela. ${ }^{8}$ Assim, no texto que examinamos, a crítica dos direitos do homem não só não se opõe ao "humanismo", mas coexiste com ele. Entretanto - o que talvez dê prova da fragilidade dessa construção teórica — mais um ano, e Marx romperia com o humanismo. Sua crítica dos direitos do homem permanecerá, $a$ fortiori, podemos dizer, nos textos da maturidade, que representam grosso modo um terceiro modelo, diante do qual os escritos de juventude até 45 (um dos quais examinamos) e os de 45-46 são, respectivamente, o primeiro e o segundo. A crítica dos direitos do homem percorre todas essas fases, embora tome uma coloração um pouco diferente, de uma fase a outra. É nesse sentido que, apesar de tudo, a crítica de Lefort não atinge apenas o jovem Marx, mas, sem dúvida, Marx e o marxismo, embora seja necessário um trabalho de interpretação, para dar conta das mudanças que ocorrem de momento a momento.

7 Embora, como veremos, o texto não se enquadre no humanismo se dermos a este conceito uma definição estrita, mais rica em termos de compreensão.

8 A emancipação "apenas" política é a que se opera com o estado democrático. Com a crítica da emancipação "meramente" política, Marx toma distância, assim, em relação ao estado democrático, e, com isso, aparentemente, também para com a democracia, em geral: “[...] não é o chamado Estado cristão [...] que é o Estado cristão perfeito [vollendete], mas antes o Estado ateu, o Estado democrático, o Estado que remete a religião para os demais elementos da sociedade civil” (Marx, I97I, pp. 82-83). Marx separa assim da ideia de democracia, que ele defendia até um ano antes. Mas o conteúdo dessa segunda emancipação só será indicado de forma progressiva. $\mathrm{O}$ apelo ao proletariado como base prática da revolução pela qual se efetuaria a segunda emancipação aparece explicitamente no outro artigo dos Anais Franco-Alemães, publicado no mesmo (único) número em que saiu a "Questão Judaica": "Para a crítica da filosofia do direito de Hegel (introdução)" (ver o final daquele texto). Quanto ao comunismo, Marx só o invocará com os Manuscritos de 1844, e ainda assim com a cláusula, a de que o comunismo, embora seja "o princípio energético do futuro próximo", não é "a finalidade do desenvolvimento humano" ou " a forma [Gestalt] da sociedade humana”. Para além do comunismo, mediação necessária, estaria "o socialismo como socialismo", forma não mediada da posição do homem (cf. ver Marx-Engels, I968, p. 546, trad. francesa, p. 99). 
É impossível fugir aqui de uma exploração mais ampla da questão do humanismo e do anti-humanismo, para defini-los melhor com vistas à análise do texto de Marx, mas também, por razões teóricas e práticas mais gerais, que ultrapassam o caso particular do pensamento marxiano.

Há mais de trinta anos (Fausto, I983), fiz uma apresentação dialético-crítica do humanismo e do anti-humanismo (espécie de dialética do humanismo e do anti-humanismo) de que resultava uma posição que não era nem humanista nem anti-humanista. Essa apresentação crítica mobilizava principalmente o tema da violência, mas também a questão do fundamento. Nela, aparecia como humanista o discurso que se fundamentava no homem, e que, ao mesmo tempo, recusava por princípio, toda violência. A essas duas características, poder-se-ia acrescentar a ideia - que serve um pouco para justificar a função de fundamento que se atribui a "homem" - de um privilégio em termos de valor da espécie humana, diante das outras espécies animais (Essa valorização se apoiava, por sua vez, frequentemente, na tese de que o mal não seria intrínseco ao homem, mas derivaria essencialmente de circunstâncias externas). Essas características definiriam, a meu ver, o humanismo, mas há certa dificuldade em decidir se elas são todas necessárias (o que daria um conceito de humanismo mais estrito e mais rico em compreensão) ou se bastaria que uma ou duas delas aparecessem para que se pudesse falar em humanismo. $\mathrm{O}$ anti-humanismo se caracterizaria pelas respostas opostas: pessimismo antropológico, recusa de toda fundação no homem, abertura mais ou menos ampla (e, em certo sentido, acrítica em relação à violência). Aqui também se poderia discutir se os três elementos são essenciais, ou igualmente essenciais, para uma definição do anti-humanismo. No que se refere ao problema dos direitos do homem, eu diria que o humanismo - pelo menos se aceitarmos a definição menos estrita é compatível tanto com a aceitação como com a recusa crítica (é o caso do texto que examinamos) dos direitos do homem $;{ }^{10}$ mas, que a rigor, o anti-humanismo é incompatível com a aceitação dos direitos do homem.

9 O que está em questão aqui é principalmente a situação da violência, e a coerência do chamado "humanismo revolucionário", de que o discurso de "A propósito da questão judaica” é precisamente um exemplo. A definição mais rica em compreensão (relativamente aos predicados que indiquei) recusaria essa possibilidade, porque nela incluí a recusa de toda violência. Essa definição é a que me parece mais rigorosa; entretanto, ela se choca com nada menos do que com o texto que é, aqui, o nosso objeto. Já observei que essa posição humanista-revolucionária dura pouco na trajetória de Marx. Se isso indica a fragilidade dessa posição, poder-se-ia discutir, porque há outros exemplos, que não remetem a uma fase transitória da carreira de um autor. Mas ela me parece, logicamente, problemática.

Io De fato, a compatibilidade do humanismo com a crítica dos direitos do homem converge (pelo menos no caso mais aparente, que é o do texto que examinamos) com a possibilidade do humanismo revolucionário, e, portanto, supõe a definição mais ampla, menos rica em compreensão, no que se refere ao leque de predicados que indiquei. 
Segundo esses critérios, Marx é humanista até I844, e nem humanista nem anti-humanista nas fases posteriores. Mais precisamente, Marx passa por três fases. Até 45-46, ele é humanista, pelo menos se adotarmos a definição mais rica em compreensão; de qualquer modo, a referência ao homem como fundamento, é aí explícita. Em 45-46, momento em que a crítica do humanismo é a mais marcada, e em que Marx se aproxima, sem dúvida, de uma espécie de historicismo, ele não é, entretanto, rigorosamente, anti-humanista. A rigor ele já não é nem humanista nem anti-humanista. Mas isso ficará mais claro na última etapa, a da maturidade (a partir de 47), quando ele se distancia do historicismo. Que, não sendo humanista (dado o teor do seu discurso e também suas declarações expressas), Marx também não é, entretanto, anti-humanista se pode ver tanto pela sua atitude em relação à violência (a violência que ele aceita é a violência-que-produz-a-não-violência), como pela sua concepção geral do homem, pelo menos nas suas possibilidades últimas.

Para além do problema histórico específico, como se posicionar hoje diante da questão do humanismo e do anti-humanismo (supondo que o problema esteja bem posto, quando é formulado naqueles termos)? $\mathrm{Na}$ minha apresentação de há trinta anos, se eu acertava as contas tanto com o humanismo como com o anti-humanismo, eu o fazia - e embora o meu procedimento dialético fosse original - seguindo exatamente (no que concerne à substância), o modelo de Marx. Hoje, continuo a não me considerar nem humanista nem anti-humanista. Entretanto, essa "posição terceira" já não coincide perfeitamente com a de Marx (de fato, a exigência de um tertius não implica em aceitar a figura que ele toma nos escritos de Marx). Diria que, para mim, duas coisas mudaram, e, na realidade, mudaram em sentidos opostos. No que se refere ao conteúdo da ideia que se faz do homem, acho que, sem absolutamente aderir a nenhum tipo de anti-humanismo, como muitos outros, incorporei um lado pessimista (que coexiste, entretanto, com um outro lado, menos pessimista) em relação à espécie. Creio que isso é inevitável, porque, como se sabe, a perspectiva de Marx sobre o homem, era, apesar de tudo, muito otimista, e pode ser dita pré-freudiana. A ideia de um homem capaz do pior, como do melhor, se coaduna melhor, aliás, com uma posição nem humanista nem anti-humanista do que a concepção um pouco idílica do homem, que, em última instância, apesar de tudo, está presente na visão marxiana. A outra coisa que mudou (para mim, e para muitos outros), é a atitude para com a violência. Sem ter me tornado humanista, avancei muito - à luz da experiência do século - no que se refere à crítica da violência dita revolucionária. Sem que se possa excluir todo recurso à violência - sempre enquanto contra-violência -, sabemos hoje com que facilidade a chamada violência revolucionária degenera em violência tout court. Se vê que a primeira revisão redobra a crítica do humanismo, e a segunda, redobra a crítica do anti-humanismo. E, assim, se a minha 
posição continua sendo nem humanista nem anti-humanista, ela não está mais calcada, imediatamente, na perspectiva de Marx. Como já sugeri, creio que esta posição atual (minha e de muitos outros) é mais rigorosamente não humanista e não-anti-humanista do que a de há trinta anos. ${ }^{\text {II }}$

\section{IV}

A crítica dos direitos do homem, como em geral a questão dos direitos do homem, tem uma história depois de Marx. Aliás, poderíamos distinguir nessa história, um ramo que é interior à tradição marxista, e um outro, que lhe é estranho.

No segundo caso, seria preciso falar pelo menos de Arendt, de Foucault, e de pós-modernos como Agamben. A respeito desses autores, vou me limitar a um certo número de observaçôes. Creio que seria importante destacar o fato de que, ao contrário do que se pensa, às vezes, neles a crítica dos direitos do homem não é em geral "absoluta", isto é, ela não é uma crítica de teor anti-humanista. Salvo erro, crítica propriamente anti-humanista iremos encontrar apenas em Agamben.

No interior da tradição marxista, os críticos dos direitos do homem, são em parte anti-humanistas (ou pelo menos, podem ser considerados assim), em parte não.

Hannah Arendt critica os direitos do homem pela sua impotência e pelas suas relações ou implicações com o projeto revolucionário jacobino, a que ela se opõe (observar que essa leitura é nesse ponto oposta à de Marx, que vê o jacobinismo como reação contra os direitos do homem). Mas em Arendt aparece uma espécie de fundamento - "os homens", a diferenciar, certo, de "homem", mas que resgata, em alguma medida, um certo tipo de fundamento que não está muito longe do que representam os direitos do homem. Foucault critica o humanismo, mas o Foucault da maturidade diz não ser contra os direitos do homem. Ele prefere a estes algo como os direitos dos governados, ideia - observa - a desenvolver e explicitar. Portanto, a crítica foucaultiana dos direitos do homem, não é uma recusa de tipo anti-humanista. É verdade que Foucault não só faz constantemente a crítica do humanismo - mas já vimos que isso não implica em anti-humanismo - como também elogia Althusser (pelo menos enquanto leitor de Marx), um autor que se auto-define como anti-humanista. Como Foucault organiza tudo isso, mereceria uma discussão maior que não posso fazer aqui. ${ }^{12}$ É em Agamben que a crítica dos direitos do homem tem um cunho acentuadamente anti-humanista: os direitos do homem seriam peças de um dispositivo repressivo o que ele denomina ban:

II Para o desenvolvimento rigoroso do tema na forma em que o dei há trinta anos, e que, se hoje me parece incompleta, mas que continuo a considerar como um momento necessário da análise, ver Fausto (1983).

I2 Ver a respeito Stival (20I5). 
ao mesmo tempo banimento da "vida nua" e "comando e insígnia do [poder] soberano" (Agamben, 1997, p. 36). Os direitos do homem aparecem como cúmplices daquilo que pretenderiam combater.

\section{V}

No que concerne à história dos direitos do homem que se situa no interior da história do marxismo, há que se referir tanto aos críticos do humanismo e dos direitos do homem, como aos seus defensores (ao comentar a história externa, simplifiquei, omitindo a trajetória do humanismo). Nessa história interior à tradição marxista, poder-se-ia dizer que houve duas tendências favoráveis aos direitos do homem, e uma contra. As favoráveis são o reformismo e o que poderíamos chamar de "centrismo" (embora, sob esse termo se perfile um grupo muito compósito). A tendência contrária aos direitos do homem é o bolchevismo. A discussão no interior do partido social-democrata russo se fez bastante em torno dos temas ligados às Declaraçôes como o da liberdade de opinião, e isto desde o Que Fazer (1902) de Lênin. Depois de 1917, o problema (ou esse tipo de problema) é central, no contexto da crítica - ou da defesa - do bolchevismo. No que se refere à crítica do bolchevismo, há que mencionar o Kautsky de pós-Outubro de I917, e Rosa Luxemburgo, tanto antes como depois de 1917.

A história do período imediatamente posterior ao golpe bolchevista de 1917 tem evidentemente uma relação de ordem geral com a questão dos direitos do homem, mas também uma curiosa relação de ordem mais específica.

Quando ocorre o golpe de Outubro, gestava-se a eleição de uma Assembleia Constituinte, velha aspiração de quase todos que participavam da luta pela emancipação. Os bolchevistas não ousaram (embora tenham considerado essa possibilidade) impedir que se votasse na mais livre de todas as eleições que a Rússia tivera até então, e talvez tenha tido em toda a sua história. Votou-se. Os bolcheviques tiveram boa votação (um quarto), mas a maioria coube aos Socialistas Revolucionários. Logo começa uma campanha oficial contra a Assembleia Constituinte. Ela realiza uma única sessão, em janeiro, elege o seu presidente, o chefe histórico Socialista Revolucionário de centro, Tchernov, vota algumas leis, inclusive a Reforma Agrária, mas é fechada (não simplesmente "dissolvida"), à força, pela intervenção dos marinheiros a serviço do regime. ${ }^{\mathrm{I} 3}$ Lênin assistiu a tudo, do antigo camarote do Tzar... Por que conto essa história em detalhe? É que os bolcheviques propõem à Assembleia, através do marinheiro Raskolnikov, um documento - uma nova declaração de direitos, que Lênin havia elaborado. ${ }^{\text {I4 }}$

I3 Marinheiros anarquistas! Esse idílio político terminará logo.

I4 Em forma integral, o documento pode ser encontrado na internet. Em forma ligeiramente 
Claro que se poderia encarar essa peça como um simples pedaço de papel com função político-pragmática, ele era isso também, mas certamente era mais. Lênin conhecia a Declaração francesa, e se dispôs a fazer uma nova. Fez, um pouco, um pastiche da antiga. E, nesse sentido, o incidente interessa muito ao tema, porque teríamos agora uma nova Declaração, que se pretende marxista. E, com ela, uma nova crítica das Declaraçôes da grande revolução. O documento leninista vai na direção da crítica às declarações do século XviII que encontramos no "A propósito da questão Judaica" (sem com isso insinuar que marxismo e leninismo são a mesma coisa). Por outro lado, ela nos ajuda a pensar a impugnação dessa crítica por Lefort.

A Declaração leninista ("dos direitos do povo trabalhador e explorado") deveria ser uma continuação das declarações francesas e americanas do século XVIII, mas - pelo menos, se analisarmos os seus efeitos e a função a que foi destinada, algo do que transparece no próprio texto - ela aparece antes como uma espécie de contra-declaração. As declarações francesas não se limitavam a declarar direitos, elas ao mesmo tempo definiam certas características, ou limites, de um Estado constitucional. Elas eram como que meta-constituições; ou constituições de constituições. Ora, a declaração de Lênin-Raskolnikov visava, pelo contrário, liquidar a Constituinte, e o poder constitucional. Foi o que se fez, de fato, naquela mesma noite. Nesse sentido, ela funcionou propriamente como o pendant (oposto) das declarações francesas. Quanto ao seu conteúdo, é importante salientar, que se nas declarações do XVIII, o conceito dominante era o de "opressão", a noção dominante da declaração russa é "exploração". Nada mais justo, se se tratasse de acrescentar a "exploração" à "opressão". Mas, salvo erro, et pas par hasard, a "opressão" desaparece da declaração. Na realidade, o que temos? Se se pode dizer que havia "ideologia" (no sentido que tentei definir) nas declaraçôes do século xvıII, deve-se afirmar que a declaração leninista era também ideológica. Por trás da condenação dos "explorados" havia uma omissão suspeita dos "oprimidos". A declaração "dos povos trabalhadores" ocultava, na realidade, uma nova dominação. Começava um novo despotismo, um neo-despotismo, diferente do Antigo Regime, porque nascido em outras condições, e "temperado" (não quero dizer "atenuado", mas marcado em seu estilo) pela democracia. O lado "democrático" do novo despotismo - na realidade, o seu lado populista, "massista" - não faz senão agravar a sua violência e dureza. De certo modo, era a vingança do Antigo Regime.

abreviada (sem o intróito), ele está em Les Droits de l'homme, antologia proposta por Gandini (1998). 
Há assim uma sucessão de declarações, mas a nova anula a primeira, pelo menos no sentido de que omite inteiramente a questão da opressão. Sem dúvida, a nova declaração aponta para um novo poder, que seria superior ao da Assembleia Constituinte, o do soviete. A questão é que no início de janeiro, a liberdade dos sovietes já ia sendo liquidada. No verão de I9I7, eles já seriam a caricatura de sovietes livres. Digamos que assim como a ideologia igualitária anti-opressão mascarava e preparava, sob um dos seus aspectos, o sufrágio censitário, a ideologia igualitária anti-exploração preparava o fantasma de um poder "soviético". O verdadeiro poder estava com o conselho de comissários, dominado por um partido que perdera as eleições, ainda que tivesse tido uma boa votação. A desconstrução lefortiana da crítica de Marx às declarações do século Xviıl, contém, implicitamente, a crítica dessa nova declaração, que é uma contra-declaração.

A análise do totalitarismo-burocrático de esquerda (e, em particular, de uma sua expressão, a Declaração Leninista de $190 \mathrm{OI})^{15}$ mostra que a presença de conceitos que se revertem continua, mas ela atinge, agora, novos conceitos: esse lugar não é mais ocupado por "homem", mas por "operário" ou "trabalhadores", ou "massa" (ver a Declaração de 1918). Isso principalmente nas expressões do tipo "controle operário", ou "poder das massas" (também "poder dos sovietes", na medida em que estes já se tornavam fantasmas).

\section{VI}

Voltemos agora à crítica de Lefort. Podemos nos perguntar: afinal, as razões de Lefort seriam legítimas? As objeçôes que ele levanta contra a crítica marxiana da Declaração dos direitos do homem, seriam justificadas? Vou examinar dois questionamentos dessa "crítica da crítica". Na realidade, existem dois textos (ou séries de textos) que, de posições diferentes, levantam objeções à argumentação de Lefort.

I) Em primeiro lugar, temos a artilharia crítica dos marxistas. Ver, a esse respeito, as consideraçôes introdutórias de Daniel Bensaid, à sua edição de "Sobre a Questão Judaica” de Marx (Marx, 2006), e também o seu L'Anti-Rocard, ou les haillons de l'utopie (Bensaid, 1980), além daquilo que escreve o seu correligionário Eustache Kouvélakis em um artigo publicado em dois números da revista Contre Temps (Kouvélakis, 2004a; 2004b).

O texto de Kouvélakis é, sob certos aspectos, melhor do que o de Bensaid, mas não resiste a uma crítica mais cerrada. Observo apenas alguns aspectos. $\mathrm{O}$ autor explica a omissão, no comentário de Marx, de certos pontos das Declaraçôes — omissão denunciada por Lefort — afirmando que Marx só queria se referir aos

I5 Na realidade, a Rússia (com dois meses de poder leninista) em que emerge a nova Declaração é ainda pré-totalitária, mas se trata de um "pré" que anuncia o totalitarismo. 
direitos do homem "enquanto eles são diferentes dos direitos do cidadão" (Kouvélakis, 2004a, p. 179). Esse argumento não tem consistência. Com ele, tenta-se dar como prova precisamente o que está em discussão. Por outro lado, a propósito da democracia (Ibid., p. I8I) o autor como que projeta o chamado Manuscrito de $43^{16}$ sobre o nosso texto, e vice-versa. É que naquele escrito, mas não no nosso, "democracia" aparece sob uma luz positiva. Aqui ela é precisamente do nível da Declaração de direitos, isto é, da ordem da sociedade dos átomos egoístas. Há aí, por parte do comentador, um curto-circuito lamentável. ${ }^{17}$ Quanto à ideia de que, para Marx, a "emancipação política" é de qualquer modo um progresso, deve-se distinguir, um progresso como simples etapa a ser eliminada, e um progresso como aquisição definitiva. O que se tem aqui é o primeiro caso, não o segundo — tem-se uma etapa de progresso, mas a ser negada. E isso fragiliza essencialmente esse progresso. Ele vale só ou essencialmente (o decisivo é que ele deve ser substituído) para a primeira emancipação, com o que, liquida-se a possibilidade de que numa etapa posterior, ele possa servir como alavanca crítico-teórica contra eventuais neodespotismos que a história venha a produzir. Aliás, voltando aos nossos críticos,

I6 Trata-se da Crítica da filosofia do direito de Hegel, textos sobre o Estado. A não confundir com a "Crítica da Filosofia do Direito de Hegel (introdução)", o texto publicado nos Anais Franco-Alemães, junto com "A propósito da questão Judaica".

I7 Kouvélakis escreve, tentando fundamentar as suas teses: "André Tosel cita [...] uma passagem do Manuscrito de 43 (chamado 'de Kreuznach') no qual Marx fala da democracia como uma forma política implicando a redução radical de toda transcendência, e [em que ele] afirma que 'o homem não existe em razão da lei, é a lei que existe em razão do homem, enquanto nas outras formas [não democráticas], o homem é a existência segundo a lei'. Parece-me [...] totalmente duvidoso — continua Kouvélakis — que o texto em questão, ou as formulações d'A Questão Judaica' possam ser citadas para apoiar a tese de Lefort. Observemos em primeiro lugar - é sempre Kouvélakis quem escreve — que Marx fala nesse texto, em termos muito poderosos da 'verdadeira democracia' como forma de superação do 'Estado político', ou do 'Estado somente político', portanto também da cidadania, o que implica necessariamente instituições, e mesmo uma Constituição, que Marx concebe como um processo de criação constitucional permanente [...]”. Observemos - agora é RF que observa - que "o texto em questão" (e "nesse texto") é o Manuscritos de 43. E que o que Kouvélakis escreve em seguida, em comentário, se refere ao Manuscritos de 43, e não se ajusta de forma alguma ao que se lê na "Questão Judaica", pois esse artigo diz precisamente o contrário (cf. Marx, I97I, p. 82-83, 84-85, 92-93, 94-95, onde a "democracia" representa o ápice da "emancipação política", isto é, da sociedade egoísta e alienada"). Kouvélakis incorpora assim ao universo do escrito de 43, que ele cita através de Tosel, "as formulaçôes da Questão Judaica”. Ou vice-versa. (Kouvélakis escreve, aliás, imprudentemente “o texto em questão ou [grifo nosso] a "Questão Judaica”). O parágrafo é organizado de tal modo que o leitor tem toda a impressão de que as teses sobre a democracia como forma não alienada valem para os dois textos, o que é inteiramente errado. $\mathrm{O}$ mínimo que se pode dizer sobre o artigo de Kouvélakis, é que ele introduz certa confusão. O máximo é o de que ele confunde deliberadamente os dois casos. Ao contrário com o que ocorre com o Manuscrito de Kreuznach, "A propósito da questão Judaica” não é um texto "democrático", e tentar criticar o arrazoado de Lefort a partir de um pretenso democratismo da "Questão Judaica" é um argumento completamente furado. 
o texto de Kouvélakis termina, como não poderia deixar de terminar, pelo elogio do bolchevismo e do golpe de Outubro.

2) Uma outra vertente crítica, na realidade, bem mais interessante, e também bastante surpreendente, vem de um liberal, Pierre Manent. Este toma a defesa do artigo de Marx, contra Lefort (cf. Manent, I98I-I982). Manent levanta vários problemas a propósito do texto de Lefort: a questão do jacobismo, a do papel do Estado, o caráter do futuro Estado-providência etc. Lefort responde a Manent num segundo texto em que aparece a questão dos direitos do homem, texto que até aqui não mencionei: "Les droits de l'homme et l'État providence" (Lefort, [1984] 1986). ${ }^{18}$ Vou me centrar numa constelação de pontos que me parece ser a essencial.

Manent escreve: "Por penetrante que seja esta análise, por fundamentada que seja a crítica dirigida contra Marx por Claude Lefort, parece-me que se deve também defender Marx contra Lefort" (Manent, I98I-I982, p. 579). A tese de Manent é a de que, quaisquer que sejam os efeitos das Declaraçōes "sobre o espaço público", produzem-se aí também certos "efeitos reais", "aqueles que Marx resume sob a noção de "egoísmo" e aos quais se refere também Tocquevile (este os subsume sob a noção de "individualismo"). Mas o essencial, é que este aspecto não poderia ser separado do primeiro, a saber, o da dissociação entre poder e saber, e da independência do pensamento. Se Marx não vê a "dissociação entre poder e saber", e a "independência do pensamento, da opinião, em relação ao poder”, é que ambas são inseparáveis "essencialmente" da "cisão entre o burguês e o cidadão", "coincidem com ela" (ne font qu'un avec elle) (Ibid., p. 580). Referindo-se a Hobbes e a Montesquieu, Manent trata de mostrar que a liberdade concedida à opinião dos cidadãos é o outro lado da sua impotência (impotência que teria algo a ver com a separação entre burguês e cidadão). E depois de citar uma passagem de "A propósito da questão judaica", em que Marx insiste sobre o que há de "enigmático" na oposição entre, por um lado, a exigência de um máximo de devoção à nação e de heroísmo que a situação imediatamente pós-revolucionária exigia, e, por outro, a elevação do homem egoísta e burguês como "o homem autêntico e verdadeiro" (Ibid., p. 58I), Manent comenta: "Eu absolutamente não conheço formulação mais clara do paradoxo da concepção política burguesa. Essas frases de Marx resumem a história do pensamento político dos séculos XVII e XVIII (Hobbes, Locke, Rousseau), tão exatamente quanto elas formulam o 'enigma' da revolução" (Ibid.).

3) Lefort responde: "Pierre Manent me imputa desconhecer o paradoxo plenamente reconhecido por Marx” (Lefort, [1984] 1986, pp. 45-46), isto é, a oposição

I8 Publicado inicialmente na Revue Interdisciplinaire d'Études juridiques, I3, Bruxelas, I984, e inserida em Claude Lefort, Essais sur le politique XIX et XX siècles, Paris, Seuil, 1986. 
entre o cidadão e o homem-mônada, egoísta. Sem negar que houvesse aí uma "contradição", Lefort se pergunta: "Mas a contradição dos homens da Revolução é a dos direitos do homem?” (Ibid., p. 580). Lefort põe em discussão também outros aspectos da argumentação de Manent. Há uma divergência entre Lefort e Manent a propósito do terror, e em geral do jacobinismo: Manent vai na direção do texto de Marx, o terror é uma espécie de contrapartida do Estado contra a sociedade civil. Lefort o vê, pelo contrário, como "a retomada sub-reptícia (en sous-main) da tradição do absolutismo" (Ibid.). Manent insistirá sobre o peso crescente do Estado que sanciona as reivindicaçōes da sociedade civil. Lefort, por sua vez, bate na tecla da originalidade dessas reivindicações, que emanam da sociedade civil, e se efetivam em conquistas sucessivas, mesmo se sancionadas pelo Estado.

Em geral, Lefort contesta o esquema da separação radical entre Estado e sociedade civil, e volta ao tema de que na gênese da modernidade há, no mínimo, muito mais do que aquilo - separação entre poder, lei e conhecimento. E quanto aos direitos do homem, recusando tanto a sua naturalização, como a sua historicização, ele os vê antes como uma espécie de "condição de possibilidade" na história (Lefort, [1984] I986, p. 52). Contra Marx e Burke, Lefort valoriza a "abstração" dos direitos do homem, a qual é na realidade "a universalidade" de um "princípio que remete o direito à interrogação do direito" (Ibid., p. 5I). A democracia, que eles exprimem ou codificam se caracterizaria pela "legitimidade de um debate sobre o legítimo e o ilegítimo" (Ibid., p. 53), e pelo "direito a ter direitos" (em sentido um pouco diferente - ele adverte - daquele que Arendt empresta à expressão). Mas fixemo-nos no ponto central, encaminhando, por outro lado, a discussão para um registro propriamente teórico, isto é, para além da querela Lefort/Manent.

Aqueles dois aspectos (liberação do espaço público e egoísmo) seriam ambos essenciais? A resposta, a meu ver, é positiva. E Lefort, à sua maneira o reconhece. Mas mesmo se Lefort reconhece que, nas Declarações, há mais do que os efeitos sobre o "espaço público", teria ele dado suficiente peso àquele outro lado? Essa questão é fundamental, e volto a formulá-la logo mais adiante. Antes disso, gostaria de observar o seguinte. Ao longo de toda essa discussão, destaca-se, nas Declarações e outros textos afins, ou o tema do egoísmo, ou então o da separação entre poder e saber etc. Porém não creio que se fale precisamente do interesse de classe. Mas o interesse de classe estaria presente enquanto tal no texto das Declaraçôes? Sem dúvida, há um lugar, em que ele desponta. Lá onde elas falam da propriedade. Como vimos, Marx insiste no privilégio da propriedade nas Declaraçôes, e ele se propõe analisar o sentido delas, à luz dessa questão (A propriedade seria o segredo das Declaraçóes. A liberdade seria a liberdade ou o direito de ser proprietário privado [cf. Marx, I97I, pp. I06-I07], a segurança, a segurança de dispor dos bens 
e da renda, quanto à igualdade "ela é igualdade da liberdade descrita mais acima" [Ibid.], isto é a igualdade da liberdade egoísta que remete à propriedade). De fato, se enfatizarmos o papel da propriedade nas Declarações, não estamos longe de encontrar o interesse de classe, mas, a verdade é que esse interesse enquanto tal não é tematizado. Se o egoísta é o burguês [Bürger], ele é igualmente e talvez principalmente o "egoísta". Em que sentido não se tem exatamente a diferença de classe, e a ideologia de classe? Primeiro, no de que, evidentemente elas estão presentes só na forma geral da oposição proprietário/não proprietário (de resto se poder discutir o quanto essa oposição é central nas Declarações). Em segundo lugar, mas não menos, porque os burgueses aparecem em forma atomizada, como a multidão de átomos egoístas. Tematizar essa última "camada" de realidade tem certamente interesse, mas ela não se confunde com a tematização da diferença de classe enquanto tal. (A meu ver, para uma análise "completa" do objeto, as duas camadas devem ser consideradas conjuntamente, e, se acrescentarmos o lado da liberação do espaço público, tal análise comportaria três estratos, o que não é o caso na "Questão Judaica"). A ausência dessa camada não é acidental, evidentemente, mas corresponde ao universo de pensamento em que se move Marx, nesse estágio da sua história intelectual. ${ }^{19}$ Essa ausência daquele tema enquanto tal no texto de Marx poderia justificar, em princípio, a sua ausência também na discussão Manent/ Lefort. Entretanto, creio que se poderia dizer — se a minha leitura é correta — que essa ausência ela mesma, deveria ter sido assinalada pelos comentadores.

Entretanto, é verdade que a denúncia do egoísmo e a do interesse de classe embora não sejam semanticamente idênticas, vão - no contexto do nosso tema - numa mesma direção. E o aspecto liberdade, separação entre poder e saber, etc., representa, de fato, o outro lado. Podemos trabalhar, apesar de tudo, com essa diferença principal. Observe-se que o termo "homem" reúne ou recobre as duas direções. Mas, com relação a uma das vertentes ele recobre ocultando; com relação à outra, ele é um "universal germinal”. No primeiro caso, ele torna invisível o que é egoísmo e interesse de classe. No outro, ele é o ponto de partida de um movimento que vai no sentido de uma situação de mais liberdade e de mais igualdade. É interessante pensar conjuntamente o jogo dessas duas direções. Quando a Declaração diz que "os homens nascem iguais" — porque essa afirmação se dá no contexto de uma sociedade de desiguais (e os constituintes sabem disso, eles que logo decretarão o sufrágio censitário) - o efeito é duplo e

I9 Que a crítica do egoísmo e do individualismo (mesmo se iluminada de um modo original) esteja presente também entre os conservadores com "fibra cívica" - Tocqueville, já vimos, se preocupa com a indiferença dos cidadãos diante da coisa pública — talvez mostre, mutatis mutandis, como o problema do egoísmo ou do individualismo não se confunde, teórica e praticamente, com a questão do interesse de classe. 
contraditório. Por um lado, se mascara a desigualdade, mas, por outro, como que se protesta contra a desigualdade. É a dialética da essência e da aparência. "Homem" é uma aparência, que, como toda aparência, diz a essência, mas negando-a. $\mathrm{O}$ efeito negativo da aparência sobre a essência é de libertação, porque a essência é opressiva (a essência é a exploração de classe). Porém, como, apesar disso, ou por isso mesmo, a aparência (homem) diz a essência, esta é confirmada, a exploração é reforçada pela afirmação dela mesma, ainda que "sob espécie" da aparência. A acrescentar: o lado da liberação (a negação da essência pela aparência) é geral e impreciso. Essa imprecisão é um defeito, mas é também uma qualidade. Porque essa imprecisão permite que se enriqueça a aparência. "Homem", conceito mais ou menos vazio, ou pouco rico em "compreensão" - para usar de uma linguagem fenomenológica irá sendo progressivamente preenchido por "homens (seres humanos) masculinos e femininos" ou por "homens (seres humanos) heterossexuais e homossexuais", etc. $\mathrm{O}$ conceito se revela, antes de tudo, germinal. ${ }^{20} \mathrm{Em}$ outra linguagem, poder-se-ia dizer, talvez, que, no juízo, "os homens são iguais", "homens" funciona como uma espécie de função proposicional muito sui-generis.

Evidentemente, o sentido mais profundo de toda essa discussão é o da significação da democracia: a democracia (o homem) se opóe essencialmente ao capitalismo (o interesse de classe ou o egoísmo) ou é a expressão dele? Um pouco as duas coisas. Porém (pelo menos no interior do pensamento crítico) a primeira determinação é mais urgente, na medida em que ela é menos aceita do que a segunda. Nas condições atuais, é muito importante mostrar a tensão, virtual pelo menos, que existe entre democracia e capitalismo.

Assim, os argumentos de Manent — alguns deles pelo menos - têm pertinência. Embora, faltasse à sua intervenção, como de resto à de Lefort assinalar a ausência (ou a presença/ausência, pois essa ausência paira como uma sombra), no texto de Marx, do locus classicus, enquanto tal, da crítica dos direitos do homem enquanto estes ocultariam as relações de classe.

Mas Lefort teria levado suficientemente em conta o lado egoísta-burguês das Declaraçôes? Seria preciso ampliar a discussão. $\mathrm{Na}$ sua concepção geral das formas sociais modernas, Lefort teria registrado como um elemento substantivo, a presença nestas de uma dualidade daquele tipo? Sem dúvida, Lefort reconhece que ela está "lá". Mas quando ele se refere às tendências "negativas" que podem aparecer

20 Ver a esse respeito, o segundo artigo de Lefort ([I984] I986), em cujo centro estão os novos direitos introduzidos pelo Welfare State, e também o livro de Gauchet (1989).

2I " [...] a problemática de Marx é posta em xeque pelos acontecimentos do nosso tempo [...] sua crítica dos direitos do homem [...] estava mal fundada. Mas isso não anula necessariamente o conjunto da critica (Lefort, [1980] 1994, p. 55, grifo nosso). "Não é arbitrário [...] considerar o direito de propriedade, enunciado no último artigo, o único qualificado 
no interior da democracia, ele as trata um pouco como se isso não fosse essencial. De fato, o que não vai na direção da democracia enquanto democracia, Lefort tende a ver como elementos da ordem da "aplicação de fato" ou da "elaboração de fato" das leis. ${ }^{22}$ Somos levados a nos perguntar se, na sua relação para com as sociedades democrático-capitalistas, Lefort não incorre no mesmo erro daqueles que tomam as violaçôes dos direitos do homem nos regimes totalitários, como coisa senão acidental, pelo menos adjetiva, não inscrita na essência, ou no "modo de constituição" dessa forma social. Ele os critica, por essa razão, no mesmo artigo. ${ }^{23}$ Ora, é como se ele caísse no mesmo engano. A violência do capital parece ser aí uma violência "de fato", não inscrita essencialmente no "modo de constituição" da sociedade em questão ${ }^{24}$. Observe-se que essa minha observação crítica não implica em subestimação da forma (nem do direito). A minha tese, que se pretende dialética, é a de que as duas vertentes - em última análise, democracia e capitalismo - coexistem, sob a espécie de uma oposição pelo menos virtual. Oposição que Lefort elide. Essa insuficiência parece se reforçar no "velho" Lefort, que talvez se encante demais com a democracia. ${ }^{25}$ Castoriadis, por sua parte, evoca esse tipo

como sagrado, como aquele sobre o qual vêm se assentar todos os outros" (Ibid., p. 56). "[...] é da ruptura [clivage] entre poder e saber aquilo de que se trata nos direitos do homem, e não apenas, não essencialmente, da cisão entre o burguês e o cidadão, entre a propriedade privada e a política" (Ibid., p. 59, grifo nosso).

22 "Na medida em que as críticas se exercem no terreno dos fatos, elas atingem o seu objetivo, seja denunciando os vícios da legislação em tal ou tal domínio, as iniquidades do funcionamento da justiça, pela crítica dos interesses e das paixões que os comandam, seja desmontando os mecanismos graças aos quais elas mostram como a sacralização da propriedade é eficaz para mascarar a oposição entre o Capital e o Trabalho" (Lefort, [1980] 1994, p. 68).

23 "Nos Estados socialistas, não são os direitos individuais que são violados, quando os homens são condenados por delitos de opinião. E não se trata de erros nem de enganos (fautes), nem de atentados acidentais à legalidade, que remeteriam a um exercício defeituoso do poder. Esses acontecimentos testemunham um modo de constituição da sociedade, a especificidade do sistema político. A vocação do poder totalitário é [...] trazer ao seu polo o pensamento público e a palavra pública; cercar o espaço público [...]” (Lefort, [1980] 1994, p. 59).

24 Insuficiências do mesmo tipo estão presentes no segundo artigo, quando Lefort ([1984] 1986) parece subestimar o alcance da ofensiva neoliberal de Thatcher e Reagan (o que é indicado por um dos críticos trotskistas, e por Hugues Poltier [2015]).

25 Para Lefort, a democracia é aquele regime em que se instaura um vazio no lugar em que se exerce o poder supremo. De fato, poderíamos observar. É verdade que há um vazio, na democracia. Mas, e se esse vazio não fosse tão significativo? E ele não é - ou pode não ser - por duas razões: 1) porque o verdadeiro poder não está lá onde se situa esse vazio, mas fora dele, por exemplo, em instituiçóes e forças econômicas nacionais ou internacionais; 2) porque, a diferença entre as figuras que, na democracia, preenchem um vazio pode não ser, ela mesma, significativa: por exemplo, as figuras são do mesmo partido, ou da mesma classe. Se o vazio é de fato preenchido por personagens diferentes, estes podem ser, entretanto, essencialmente iguais nessa sua diferença. Seria fácil dar exemplos, tanto 
de insuficiência, sem nomear explicitamente o seu ex-aliado. ${ }^{26} \mathrm{Na}$ realidade, já há abuso ou erro, em denominar as assim chamadas "sociedades ocidentais" de "democracias". Mas chamá-las de "sociedades capitalistas", também é insuficiente. Elas são — oxímoro objetivo —: democracias capitalistas. Lefort não chega até aí. Falta dialética ao seu pensamento? Provavelmente sim, como acontece em quase todo o pensamento francês. Mas, observe-se que o que falta (se o meu argumento é válido) é dialética funcionando num registro "pós-marxista" e não marxista. Marx conhecia essa contradição, mas, não lhe deu destaque no plano do projeto político, pelo menos. E Castoriadis? Se também não há, a rigor, muita dialética no pensamento - também notável — de Castoriadis ${ }^{27}$, ele acerta ao descrever as democracias capitalistas, ou "oligarquias liberais", como ele prefere, como sociedades cujo estatuto dos indivíduos é contraditório (aqui se trata da dualidade cidadão/agente econômico; há também uma outra, diferente, que está em Marx, a de suporte/sujeito, simples agente do processo e ator ativo). As formaçôes modernas seriam, para ele, verdadeiras sociedades esquizofrênicas.

4) O que concluímos? É preciso juntar os dois polos, unir os dois aspectos fundamentais. Se "homem" se reverte em "homem egoísta" ou em "homem burguês" ou em "indivíduo proprietário", o que quer dizer: "homem" — enquanto tal, generalidade, universalidade - é diferente de "homem"; também se deve dizer que "homem" é igual a "homem". De fato, também há verdade na afirmação — pelo menos como proposta ou projeto — "os homens são iguais" —; ela teve e tem efeitos múltiplos. Conclusão: "homem" é e não é igual a "homem". O que se escreve, em hegelianês, isto é, em termos da Lógica de Hegel: há "identidade da identidade e da não identidade", ou mais simplesmente, "unidade da identidade e da não identidade".

A fórmula vale como crítica do capitalismo - para as democracias capitalistas - mas abrange também a crítica dos totalitarismos. Nas democracias capitalistas, na aparência [Erscheinung], temos homem = homem; e na realidade efetiva [Wirklichkeit] homem $\neq$ homem. Nas sociedades burocrático-totalitárias (de esquerda), a aparência é essencialmente negativa (sem, com isso, deixar de ser em si mesma ideológica, isto é, mistificante): afirma-se uma oposição à desigualdade, isto é, ao homem $\neq$ homem, que é a essência do capitalismo. Mas na realidade

do caso I como do caso 2.

26 Ver a propósito do “vazio", Castoriadis (I998, p. I58). Mas há outras passagens críticas. Dei várias referências atinentes em Fausto (20I2).

27 Esse déficit de dialética aparece, a meu ver, nas dificuldades que ele revela em entender as determinaçôes contraditórias que reproduzem contradiçôes objetivas (a distinguir das insuficiências efetivas, que também existem) no interior da obra de Marx. Ver a respeito, o ensaio 3, da segunda parte de Fausto (2015, p. I23 e ss). 
efetiva das sociedades totalitárias de esquerda, tem-se também a desigualdade homem $\neq$ homem, porém em forma diferente da do capitalismo: a desigualdade vem imediatamente na própria dominação. Embora se apresente em forma crítica, a aparência nessas sociedades é em si mesma ideologia, porque nela se tem uma negação abstrata do capitalismo, mais precisamente, uma negação abstrata da ideologia homem $=$ homem. Na realidade, passa-se do que deveria ser uma negação dialética da ideologia capitalista a uma negação abstrata. $\mathrm{Ou}$ - o que remete ao mesmo - em vez de afirmar a identidade da identidade e da não identidade — a democracia se interverte em não-democracia, mas ao mesmo tempo é igual a ela mesma (democracia $=$ democracia $)$ - afirma-se apenas o primeiro membro da expressão, isto é, a não identidade "a democracia se interverte em não-democracia" (democracia $\neq$ democracia). Assim mutilada, a fórmula geral é mistificante.

\section{VII}

Como vimos, a análise do totalitarismo-burocrático de esquerda - e, em particular, de uma expressão sua (ou que a anuncia) a Declaração Leninista de I9I8 mostra que o lugar dos conceitos que se revertem (ou intervertem) não é mais ocupado pela noção de "homem", mas por noções como as de "operário" ou de "trabalhadores", ou de "massa".

Mas houve também um outro totalitarismo.

O nazismo representa o neodespotismo de direita, aquele que não surge pelo lado dos revolucionários, mas, em forma geral, pelo dos grupos e classes dominantes. Ele representa um segundo vetor neodespótico: o primeiro brota no campo revolucionário; este segundo irrompe no caldo das forças antirrevolucionárias.

$\mathrm{O}$ que se tem no nazismo, em particular relativamente às Declaraçôes? O nazismo é, sob certo aspecto, o grau zero da ideologia. Brutalidade em estado puro. Mas ao mesmo tempo, ele tem uma ideologia, o que complica as coisas. Por um lado, ele privilegia a desigualdade, assume a desigualdade. Nesse sentido, ele é - como os nazis sempre declararam - o oposto dos princípios de 89. Como tentei mostrar alhures, contra certas ideias correntes, de extração marxista, o nazismo representa muito mais uma ideologia anti-89 do que uma ideologia que se definiria na sua relação com o capitalismo (ou um pró-capitalismo ou um anti-capitalismo). De fato, a desigualdade que ele abraça não é a do proprietário, nem a do capitalista. Ela se instaura pela presença do chefe ou guia, isto é, por uma dominação de caráter imediato, mas de variedade diferente da que encontramos nos totalitarismos de esquerda. Contudo, além de se opor às Declaraçôes pelo seu

28 Isso principalmente na forma das expressōes do tipo "controle operário", ou "poder das massas", como também "poder dos sovietes" (dos sovietes que já iam se tornando fantasmas). 
horror à igualdade, o nazismo as recusa também em um segundo sentido. De fato, há na ideologia nazista, um elemento estranho às Declaraçôes, a "comunidade". É verdade que elas evocam, "o corpo social", "o povo francês", e - a Declaração de 89 - também a "Nação" (ver artigo $3^{\circ}$ daquela Declaração). Mas o nazismo evoca as relações de "sangue" - a "comunidade" de terra e de sangue - encarando o povo alemão como se se tratasse de uma grande família. A comunidade toma o lugar da "sociedade" (sociedade de átomos), retomando uma diferença clássica, mas ela não é o equivalente da nação - é a sua hybris. O nazismo se apresenta, assim, como sendo duplamente anti-89. Ele retoma negativamente as duas vertentes consideradas mais acima: é, ao mesmo tempo, anti-individualista e anti-igualitário (ou anti-libertário).

Se quisermos expor essas determinações em forma dialética mais precisa (o que passa, como nos outros casos, pela distinção entre a aparência do nazismo e a realidade efetiva dele), teríamos o seguinte quadro: na aparência (isto é, no plano da ideologia) tem-se uma recusa da identidade homem $=$ homem que está na aparência das sociedades democrático-capitalistas. Ao contrário destas, o nazismo afirma a hierarquia e a desigualdade. Por outro lado, ele afirma (sempre no plano da aparência) a comunidade o que representa também uma recusa da identidade homem $=$ homem (pois a comunidade inclui desiguais) mas que tem a particularidade de ser o oposto do "individualismo" (que está presente tanto na ideologia como na realidade efetiva das democracias capitalistas). $\mathrm{Na}$ realidade efetiva do nazismo tem-se, como na sua aparência, desigualdade. Mas na forma de uma dominação, digamos, imediata, diversa da desigualdade presente nas democracias capitalistas e de variedade diferente da desigualdade imediata constatável nos totalitarismos de esquerda. A diferença para com o capitalismo já está expressa no fato de que há não só desigualdade, mas também uma hierarquia, como efeito imediato. Mas, se, no nazismo, a desigualdade está nos dois níveis, na realidade efetiva dele não há o outro elemento da sua aparência, a "comunidade".

Resumindo: em forma geral, tem-se na ideologia nazista a desigualdade homem $\neq$ homem (o que lhe é próprio e característico) e objetivamente também "homem $\neq$ homem", o que ocorre em forma genérica também nas outras formas. Mas com a diferença de que no nazismo se trata antes de "homem contra o homem" (em sentido forte), "o homem dominando imediatamente o homem", e no limite, o destruindo.

\section{VIII}

Assim, chegamos à ideia de uma modernidade essencial — de posição ou de recusa - das Declaraçôes. Modernidade que é evidenciada tanto pela realidade do capitalismo (o capitalismo as recupera como ideologia, mas elas contêm um 
gérmen crítico, há de resto, capitalismos autocráticos e populistas), como pelo dos totalitarismos. E a respeito destes últimos, já que estamos falando das Declarações e dos direitos dos homens, convém lembrar que há hoje outros totalitarismos além daqueles a que me referi, os de caráter fundamentalista-religioso (islamista, mas não só), que se definem de maneira talvez ainda mais clara do que o nazismo, como ideologias anti-1789. Eles entram, a rigor, no quadro dos totalitarismos de direita, mas representam uma variedade muito particular.

As Declaraçôes nos "servem" hoje, embora, nelas haja, como se viu, uma "incompletude". Esta se corrige, em parte, de forma imanente, pelo próprio caráter "germinal" das Declaraçôes (elas estão pelo menos abertas às particularizaçôes), mas essa circunstância não dispensa a crítica. Tudo se passa como se fosse sempre necessário trabalhar tanto com a identidade como com a não-identidade. Quero dizer com isto: é preciso reafirmar tanto a identidade como a não-identidade. Mas, com a emergência dos totalitarismos, há como que a exigência ou o reforço da reafirmação da identidade (a democracia $=$ democracia $)$. Essa autonomia da (exigência) de identidade nos levaria para além da dialética? Sim e não. O programa crítico que se impõe nos nossos dias poderia ainda ser formulado, em conjunto, em forma dialética, retomando a fórmula da identidade da identidade e da não identidade. Só que é como se tivéssemos de acrescentar a ela mais uma identidade. Assim: I) a democracia se interverte ou pode se interverter no seu contrário, ela é também igual a ela mesma. A democracia oculta o capitalismo, mas ao mesmo tempo é não só expressão das liberdades fundamentais, mas, dentro de certas condições, vetor essencial e constitutivo de luta contra o capitalismo; 2) por outro lado (isto, o novo, diante da posição clássica), há que afirmar a identidade da democracia, lá onde ela não aparece apenas deformada, mas é radicalmente negada.

É como se tivéssemos hoje: identidade, identidade da identidade e da não identidade (o ponto é o símbolo lógico que exprime a conjunção lógica, "e").

\section{IX}

Mas qual o significado mais geral, e também mais profundo, dessa presença atual das Declaraçôes? Elas não podem ter apenas uma função "utilitária", como observa Lefort. Elas exprimem as ideias do que se chamou de a Grande Revolução, na realidade, a primeira Revolução (se supusermos que haverá, ou já está havendo, uma segunda, de outro caráter). E se, como quer Lefort, as Declaraçôes continuam representando "uma política" (mesmo se essa política não esgota a totalidade do programa), é que a primeira revolução, dois séculos depois, da sua ocorrência, não se completou, isto é, não está ainda plenamente realizada.

O programa de 89 é atual porque vivemos em parte ainda uma situação de pré-89. Primeiro, porque a revolução democrática não cumpriu todas as suas 
promessas. A sombra da antiga opressão aflora nas múltiplas taras das democracias contemporâneas. Em segundo lugar, por força da sobrevivência, ou antes, da ressurgência do despotismo, tanto na figura dos neo-totalitarismos capitalistas-comunistas do tipo chinês, como na dos totalitarismos fundamentalistas-religiosos. Essa dupla presença, explica o porquê da atualidade das Declaraçôes. Vivemos no ritmo do pós-89, mas há ao mesmo tempo um registro pré-89 que está duplamente em vigência. Na contra-mão do esquema da "revolução permanente", estamos diante da necessidade de uma espécie de "rattrapage" da primeira revolução.

O tema da relação entre as duas revoluções esteve sempre na base das discussōes no interior da esquerda. A resposta que hoje se impõe é uma resposta não bolchevista (o bolchevismo propõe uma ruptura entre as duas, junto com a reabilitação do jacobinismo, o que só na aparência é paradoxal), mas também não reformista (o reformismo propunha a simples continuidade entre as duas revoluções). Dentro dessa terceira possibilidade, se reconhece, sem dúvida, continuidade e descontinuidade entre as duas revoluções, mas se recusa absolutamente o Terror, que antecipa, à sua maneira, o descarrilamento totalitário de todo o processo.

\section{Referências}

Agamben, Giorgio (1997). Homo Sacer. I, Le pouvoir souverain et la vie nue, trad. Marilène Raiola, Paris: Seuil (Original italiano).

Bauer, Bruno (I843a). "Die Fähigkeit der heutigen Juden und Christen, frei zu warden", In Einundzwanzig Bogen aus der Schweiz, S. 56-7I, Zürich und Winterthur ("A aptidão de judeus e cristãos de hoje a se tornarem livres", em Vinte e uma folhas da Suiça).

Bauer, Bruno (1843b). Die Judenfrage, Braunschweig (A questão judaica).

Castoriadis, Cornelius (1998). Figures du Pensable. Les carrefours du labyrinte, 4, Paris: Seuil.

Fausto, Ruy (20I5 [1983]). "Sobre o Jovem Marx", In Ruy Fausto, Sentido da Dialética (Marx, lógica e politica), São Paulo: Vozes.

Foucault, Michel (2004). Naissance de la Biopolitique, Paris: Gallimard/Seuil.

Foucault, Michel (20I2). "L'héritage de Lefort et de Castoriadis, critiques de Marx”, In Juliette Grange; Pierre Musso, Les Socialismes, Paris: Le bord de l'eau.

Gauchet, Marcel (1989). La Révolution des Droits de l'homme, Paris: Gallimard.

Gandini, Jean-Jacques (1998) (Éd.). Les Droits de l'homme, Paris: Librio, ejL.

Halevy, Elie (1995 [1902]). La Formation du Radicalisme Philosophique, 3 vols., Paris: PUF. 
KouvéLAKIs, Eustache (2004a). "Critiques de la citoyenneté, Lefort et Balibar, critiques de Marx", Contretemps, Paris, n. 9, fév.

KouvéLAKIs, Eustache (2004b). "Critique de la citoyenneté (2), Marx et la question juive", Contretemps, Paris, n. Io, mai.

Lefort, Claude (198I). L'Invention Démocratique. Les limites de la domination totalitaire, Paris: Fayard, 1994.

Lefort, Claude (1986 [1984]). "Les droits de l'homme et l'État providence", In Claude Lefort, Essais sur le politique. XIX et XXe siècles. Paris: Seuil.

Manent, Pierre (I98I-I982). "Démocratie et totalitarisme, a propos de Claude Lefort", Commentaire, Paris, v. 4, n. I6.

MarX, Karl (197I). A propos de la question juive, trad. Marianna Simon, Paris: Aubier Montaigne, Edição bilíngue (alemão e francês).

Marx, Karl (2006). Sur la Question juive, trad. Jean-François Poirier, Paris: La Fabrique.

MarX-Engels (1968 [I844]), Werke, Ergänzungsband, Erster Teil, Ökonomischphiosophische Manuskript (I844), Berlin, Dietz, p. 546 (Manuscrits de 1844, trad. E. Botigelli, Paris, Éd. Sociales).

Poltier, Hughes (2015). "La question de la politique dans la pensée du politique de Claude Lefort", In Nicolas Poirer (Dir.), Cornelius Castoriadis et Claude Lefort: l'expérience démocratique, Paris: Le Bord de l'eau.

Stival, Monica (20I5). Moral e Política em Foucault, entre a crítica e o nominalismo. São Paulo: Loyola. 